Idowu, S. A., Ifedayo, T. E., \& Idowu, E. O. (2020). Assessing the Career Conflict Options of Senior Secondary School Students of Ado-Odo Ota Local Government, Ogun State, Nigeria.

\title{
Assessing the Career Conflict Options of Senior Secondary School Students of Ado-Odo Ota Local Government, Ogun State, Nigeria
}

\author{
Samuel Adebayo Idowu* \\ University, Ilara-Mokin, Ondo State, Nigeria \\ Tolu Elizabeth Ifedayo \\ Elizade University, Ilara-Mokin, Ondo State, Nigeria \\ Elizabeth Oluwatoyin Idowu \\ of Education, Ijagun, Ogun State, Nigeria

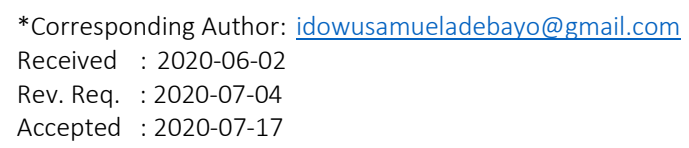

Department of Human Resource Management, Faculty of Humanities, Social and Management Sciences, Elizade

Department of History and International Relations, Faculty of Humanities, Social and Management Sciences,

Postgraduate Student, Department of Counselling Psychology and Educational Foundation, Tai Solarin University

do

DOI: $10.46303 /$ ressat.05.03.3

\begin{abstract}
Idowu, S. A., Ifedayo, T. E., \& Idowu, E. O. (2020). Assessing the career conflict options of senior secondary school students of Ado-Odo Ota Local Government, Ogun State, Nigeria. Research in Social Sciences and Technology, 5 (3), 55-77.. https://doi.org/10.46303/ressat.05.03.3

\begin{abstract}
Career choice is one of the most important decisions that students make, and this decision will affect them throughout their lives. This study adopts a descriptive research survey method for assessing career conflict options of senior secondary school students in Ado-Odo Ota Local Government, Ogun State, Nigeria. The data contains questionnaires administered to 373 male and female secondary school students from three private schools and three public schools in the Ado-Odo Ota Local Government. The data obtained from the questionnaires were categorized into a Demographic Data Inventory, Career Choice Scale, and Support, Interference, and Lack of Engagement Scale. Demographic information was analyzed using descriptive statistics, and simple linear regression analysis was used to test the three hypotheses generated for the study at 0.05 alpha levels of significance. The findings suggest that parental formal education has a significant effect on the choice of careers of students, and that the profession of parents has a minor influence on the choice of careers of students. The results also indicate that the socio-economic status of parents does not affect the career choice of secondary school students. Based on the findings, this study recommends that parents be trained in career counseling to help parents direct their children in their career choices. Counseling units in the Ministry of Education should also coordinate orientation activities and provide information on the broad variety of career opportunities open to students. Finally,
\end{abstract}


Idowu, S. A., Ifedayo, T. E., \& Idowu, E. O. (2020). Assessing the Career Conflict Options of Senior Secondary School Students of Ado-Odo Ota Local Government, Ogun State, Nigeria.

future research should be carried out on the contradictory effect of teachers and school counselors on the career choices of secondary school students.

Keywords: Career choice conflict, parents' education, parents' occupation, secondary school students

\section{Introduction}

There is nothing as important for students as choosing a career. At times, the option of an individual's career determines the ultimate success of an individual in all life endeavors. Career choice affects every aspect of a student's life; a successful career choice could determine one's potential success in the same way that a bad career choice could inhibit one's chance of success. Choosing a career is a vital decision that everyone has to make at some stage in their lives. Career choice is a decision that not only informs a student of a variety of subjects in secondary school but can also impact their course of study in higher learning institutions. As a result, most secondary school students (especially those in senior classes) understand the value of obtaining appropriate career and educational information from parents, teachers, and relatives (Camarero-Figuerola, Dueñas, \& Renta-Davids, 2020).

The decision to make a better career choice has always led to contradictory thoughts in the minds of students, leading to intra-personal conflict. Intra-personal conflict is the kind of conflict that occurs within an individual based on ideas, beliefs, decisions, and choices. This type of disagreement in career choices can either contribute to or hinder a student's career prospects. A range of factors, including parents, family, career interests, education policy, student academic success and employment opportunities, affect the options of career choices made by students. Choosing a career is often seen as a major turning point in the life of secondary school students (Borchert, 2002; Hall \& Quinn, 2014; Napompech, 2011) because the conflicting decision itself has the power to open the door to success or close the door to opportunity.

Students are aware of career opportunities and choices as soon as they are introduced to the occupation, ambitions, education, and role of their parents in society (Chen, 2018; Patton \& McMahon, 2014). Parents have often seen themselves as having a major impact on their child's career choices. This is due to the fact that parents see themselves as family leaders who guide, prescribe, and determine the behavior and actions of their children in order for the children to achieve the goals and objectives set (Idowu, 2019). Adelusi (2003) argues that parents may be a motivating or inhibiting force in their children's career choices, particularly when it is clear that the home is the first social group in which the child comes into contact with parents who are the most powerful determinants of their children's career plans, ambitions, and career expectations. According to Alutu (2001), career choices should begin as early as the nursery school years at all levels of primary, secondary, and tertiary education. The career-choice cycle of young people can be likened to the polisher crystals: All kinds of people grind at them, but the parents are the biggest rocks in the tumbler (Otto, 2000). 
Idowu, S. A., Ifedayo, T. E., \& Idowu, E. O. (2020). Assessing the Career Conflict Options of Senior Secondary School Students of Ado-Odo Ota Local Government, Ogun State, Nigeria.

According to Carlos (2009), knowing the factors that contribute to choosing a career is crucial because that decision sets goals for one's future and can influence one's satisfaction with one's career. Parents are the most important people their children turn to, especially as counselors and role models (Kracke, Hany, Driesel-Lange, \& Schindler, 2013). Watson, Quatman, and Edler (2002), Polenova, Vedral, Brisson, and Zinn (2018), and Sylaj and Sylaj (2020) argue that career preferences are partly determined by factors such as parents' level of education, socioeconomic status, parental occupation, and parental expectations. Vellymalay (2012) says that the child's ability to excel in school depends on how well the child is handled by the parents. Thus, this study is significant because parents do not understand the major impact their educational background, occupation, socio-economic status, and beliefs have on the career choices of their children. It is on this basis that the purpose of this study is to explore the degree to which parental factors predict the career choices of senior secondary school students in the Ado-Odo Ota Local Government Area of Ogun State, Nigeria.

\section{Objectives of the Study}

The aim of this study is the assessment of career conflict options of senior secondary school students of Ado-Odo Ota Local Government, Ogun State, Nigeria. Other objectives that were critically studied are:

1. To examine the impact of parents' level of formal education on the career choices of senior secondary school students.

2. To assess the extent to which parents' occupation affects the career choices of senior secondary school students.

3. To determine the relationship between parents' socio-economic status and the career choices of senior secondary school students.

4. To outline recommendations and develop suggestions for future research to parents and other stakeholders when making career choices for senior secondary school students.

\section{Research Hypotheses}

Ho1: Parents' level of formal education has significant impact on the career choices of senior secondary school students.

Ho2: Parents' occupation has no significant impact on the career choices of senior secondary school students.

Ho3: Parents' socio-economic status has no relationship with the career choices of senior secondary school students. 
Idowu, S. A., Ifedayo, T. E., \& Idowu, E. O. (2020). Assessing the Career Conflict Options of Senior Secondary School Students of Ado-Odo Ota Local Government, Ogun State, Nigeria.

\section{Review of Relevant Literature}

\section{Career Choice}

Career is the entirety of the work that one does in his or her lifetime. According to Granger, Dick, Jacobson, and Van-Slyke (2007), a career describes the totality of one's activity over a lifetime. Alika and Egbochuku (2009) define a career as a sequence of occupations, jobs, and positions occupied in a person's working life; this can be applied to pre-vocational and postvocational roles as well. Brown (2002) describes the process of choosing a career as one of estimating one's abilities and values, of estimating the skills and abilities needed for success in a given occupation, and of estimating the job values that will be met by the various occupational alternatives accessible. Career is a series of jobs that a person has in a specific field of work, usually requiring more responsibilities as time passes (Okonkwo, 2011). Okobiah and Okorodudu (2004) refer to career as a range of work and non-work circumstances that typically cover an individual's entire life.

Career choice is a process involving a comparison of available career opportunities, a narrowing of choices, and a determination of what is best suited to a person at that time (Capuzzi \& Stauffer, 2012). Career choice is the outcome of a series of decisions, transactions, and changes over a period of years and in the context of many influencing factors (Leung, 2008). Career choice is a decision that most human beings make at some point in their lives; it is a decision that should be carefully considered as it can affect the rest of a person's life (Eyo, 2011).

According to Salami (2006), many young people in Nigeria make a wrong career choice because of ignorance, inexperience, advice from parents and teachers, or because of the stigma attached to those jobs without sufficient technical guidance and career advice. Career decisionmaking provides a mechanism that enables creativity and efficient and sustainable approaches to the problem of youth career development (Savickas, 2012). Muraguri (2011) argues that the individual's choice of career is likely to be affected by several factors including personal and cultural values, family background, career expectations, and career guidance. Some often make career decisions by choosing the path of least resistance: for example, pursuing a career path favored by their parents or following in the footsteps of elder siblings.

Finally, career choices are not made in isolation. Secondary school students are exposed to the systemic influence of their parents and the social and cultural classes to which they belong. Countless variables affect the phases that students go through when selecting a career. Once students are in secondary school, they have the overwhelming job of selecting their future careers. Career choice is one of the most daunting tasks for some secondary school students, as it determines what they would do in the future. It is therefore very important for each person to choose an appropriate career (NCDA, 2003) as this helps to decide their future. 
Idowu, S. A., Ifedayo, T. E., \& Idowu, E. O. (2020). Assessing the Career Conflict Options of Senior Secondary School Students of Ado-Odo Ota Local Government, Ogun State, Nigeria.

\section{Parents' Educational Background}

The educational background of parents may affect the choice of a student's career, as certain students may determine whether or not to choose the career of their parents. Udoh and Sanni (2012) examined the impact of parental background variables on the career choices of secondary school students in Nigeria's Uyo Local Government Area. The findings indicate that the level of formal education of parents has a major impact on the career aspirations of secondary school students. Aswani (2012) argues that parental education has a major effect on pupils' educational and vocational aspirations. In the same way, Adya and Kaiser (2005) see the importance of parental education as important motivators for their children. For example, Montgomery (1992) points out that female students with talent in mathematics regarded their career choices as reflecting interests resulting from the influence and educational history of their parents.

Onyejiaku (1980) asserts that well-educated parents are better able to provide the requisite assistance to their children in career choice and planning. Denga (1990) found that children may be disinterested in some careers because of the educational inadequacy of parents and thus may not be educated. Whiston and Keller's (2004) study in Latin America on the impact of the family found that parental education had an impact on what the child learned about work and work experience. Several researchers also reported the strong impact of parents' education on career choices (Esters \& Bowen, 2005; Fisher \& Griggs, 1995).

In a study conducted by Nwoke (2011) on the impact of parents' educational background on vocational choice among Nigerian adolescents from eight secondary schools in Abuja Municipal, it was observed that parents' educational background appears to influence and stimulate the type of courses that children study in tertiary institutions and their subsequent career choices. Deridder (1990) points out that a lower level of parent education can delay the career development of adolescents. Being born to parents with poor education reduces the likelihood of achieving a career goal and ultimately determines the child's likely career path.

\section{Parents' Occupation}

Parents have a great deal of importance in their children's career choices, which is why career discussions between parents and children play a key role in children's career choices. Muyoi (2009) believes that parents have an effect on children's career decisions, both deliberately and unintentionally; as children pass through puberty, they begin to seriously consider their future, often looking to their parents as role models or career guides. Lee (1984) argues that the occupational orientation of parents familiarizes children with their roles in the workplace. Hairston (2000) states that the career ambitions of the parent encourage children to select their career goals, which often affect their knowledge of careers and familiarize them with 
Idowu, S. A., Ifedayo, T. E., \& Idowu, E. O. (2020). Assessing the Career Conflict Options of Senior Secondary School Students of Ado-Odo Ota Local Government, Ogun State, Nigeria.

occupational requirements. Parents provide adequate encouragement for career choices that appear to be appropriate to their own (Small \& McClean, 2002).

Otto (2000) estimates that 93 percent of high school juniors in his sample reported having similar occupational values to their parents. If the experience is good, then the child wants to associate with the occupation, but if it is negative, the child refuses the occupation. Jungen (2008) states that children begin to associate with the profession of their parents as soon as they are able to pronounce their work title. Caplow (1994) found that career decisions are explicitly and specifically inherited from parents. Krippner (1963) analyzed the occupational preferences of students and their parents' occupational level using Roe's (1956) occupational scale and discovered that the occupations that students wanted to join are related to that of their parents' occupations. Roe (1956) perceives some positive relationship between children's early childhood experiences and their occupational choice, as they spend most of their years at home and generally find the family as their reference community and parents to be significant figures.

According to Onyejiaku (1987), children born in a home dominated by a certain profession are likely to be influenced by that profession. Many families are known to have held some occupations for many generations. A boy whose father and grandparents, uncles, and brothers are doctors or lawyers would inevitably have a different professional interest from a boy born in a family established over the years as farmers, teachers, or accountants. Udoh and Sanni (2012) discovered that the occupations of parents have a major effect on the career choices of secondary school students in Uyo LGA. Paul (1962) argues that some parents have a participatory attitude to their children's career choices. Parents with this kind of attitude are keen on their jobs and speak openly and with obvious enthusiasm to their children, thus exposing their children to these occupations (Paul, 1962).

\section{Parents Socio-economic Status}

A variety of family-related factors, such as the socio-economic status of parents, impact the child (Bollu-steve \& Sanni, 2013). From a research study on family impacts on career development, Lankard (1995) describes the socio-economic status of parents as having an impact on career choices among young people. Alika and Egbochuku (2009) reported that parental influence has a major impact on the educational attainment of adolescents, especially on the socio-economic status of parents. Shahidul, Karim, and Mustari (2015) found that students' career ambitions are significantly affected by the socio-economic background of their families. Obiyo and Eze (2015) point out that, in general, social status is passed down through generations and typically affects individual career choices. It is similar to Cosidine and Zappala (2002), who found that the socio-economic status of parents substantially influences the educational history of underprivileged students. 
Idowu, S. A., Ifedayo, T. E., \& Idowu, E. O. (2020). Assessing the Career Conflict Options of Senior Secondary School Students of Ado-Odo Ota Local Government, Ogun State, Nigeria.

At one point, according to Bolles (2011), you inherit some financial and other resources from your parents that affect your career choices to some degree. The financial status of the family influences factors such as one's attending school and one's career choice. In turn, this can have an impact on one's own values and career aspirations. Gabriel, Muli, Muasya, Maonga, and Makhungilhu (2016) also find that the socio-economic background of the student's family has a major impact on their career ambitions. Students from high-level socio-economic households tend to join skilled work while those from low-income households are content with clerical work. However, Obiyo and Eze (2015) argued that the socio-economic status of parents is not a good predictor of the career ambitions of secondary school students. According to Taylor, Harris, and Taylor (2004), the socio-economic status of parents is insignificant in shaping their career aspirations.

\section{Theoretical Framework Adopted for this Study}

This study is guided by the Parental Attachment Theory proposed by Bowlby (1980). The theory explains that a child develops a deep emotional relationship with another adult (caregiver) over a lifetime. Parental attachment, according to Navin (2009), has been shown to be positively correlated with student career exploration. Navin (2009) considers that parental attachment is defined as the degree to which one feels emotionally attached and supported by one's parents, which is positively linked to career exploration. Bowlby (1980) suggests that sensitive and emotionally open parenting helps the child develop a healthy relationship style that promotes the child's socio-emotional development and well-being. Less supportive and emotionally open parenting or neglect of the child's needs result in unhealthy types of attachment style, which is a risk factor for many mental health problems.

Lee and Hughey (2001) found that parental attachment is positively related to career maturity, which is characterized as how a teenager is prepared to make career choices. Although career maturity may not be related to career exploration, career exploration is a required step in the process of achieving career maturity. The theory is relevant to this study, given that Bowlby (1980) provides guidance on children's emotional development. Bowlby (1980) has also made fair suggestions to parents and guardians. Parents and guardians can now see the need to build a safe bond of attachment to their children. Such bonds will enable children to end up with a secure attachment and a secure state of mind later in life. Parents should learn to consider the biological and psychological needs of children and to reduce the unreasonably high standards of behavior of children. In this way, parents may seek to avoid the frustration that comes with expecting events beyond the child's ability. Some studies have suggested that the explanation for the correlation between parental connection and various aspects of career growth is that a secure relationship with one's parents provides a safe place for one to seek emotional support (Navin, 2009).

\section{Data and Method}

Research Design 
Idowu, S. A., Ifedayo, T. E., \& Idowu, E. O. (2020). Assessing the Career Conflict Options of Senior Secondary School Students of Ado-Odo Ota Local Government, Ogun State, Nigeria.

This study adopts a quantitative research design to assess career conflict options of senior secondary school students. According to Christensen, Johnson, and Turner (2019), the quantitative research design is the strategy for gathering information from the study participants in a numerical format. The type of quantitative research design adopted for this study is the descriptive survey design that helps the researchers to gather data from a crosssection of the target population about an existing phenomenon (Leedy \& Ormrod, 2001). This design is used because no attempt is made to manipulate any of the variables in this research; they are represented as they exist among the participants in this study.

This research is a survey-based quantitative case study associated with a deductive approach. A deductive approach occurs when the conclusion is logically derived from a set of premises, the conclusion being true when all premises are true (Ketokivi \& Mantere, 2010). Firstly, it is a case study concentrating on three private and three public secondary schools in Nigeria. Secondly, the study collected primary data by means of a survey approach by developing a questionnaire. Finally, this research examined parents' education, occupation, and socioeconomic status (independent variables) as having an effect on the career choices of secondary school students (dependent variable).

\section{Population and Sample}

The population of this study consists of 12,200 SSS1, SSS 2, and SSS 3 students from 77 public and private secondary schools in the Ado-Odo Ota Local Government Area of the State of Ogun, Nigeria (Ogun State Government Official Website, 2020) during the 2019/2020 academic session.

A sample of 373 participants were drawn from the population using a multi-stage random sampling technique. The sample size was calculated by applying the formula of Yamane (1973) with $95 \%$ confidence level, which is given below:

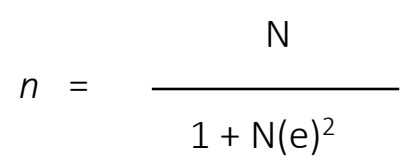

where $n$ is the sample size, $\mathrm{N}$ is the population size, and e is the error margin (alpha value).

1

$n=\quad \begin{aligned} & 1+12,200(0.05)^{2} \\ & =373\end{aligned}$


Idowu, S. A., Ifedayo, T. E., \& Idowu, E. O. (2020). Assessing the Career Conflict Options of Senior Secondary School Students of Ado-Odo Ota Local Government, Ogun State, Nigeria.

Table 1. Distribution of the Selected Sample (2019/2020 Academic Session).

\begin{tabular}{|l|l|l|c|c|c|}
\hline $\begin{array}{l}\text { School } \\
\text { Type }\end{array}$ & S/N & Selected Schools & $\begin{array}{c}\text { Total \# of } \\
\text { Students }\end{array}$ & $\begin{array}{c}\text { Sampling } \\
\text { Fraction }\end{array}$ & $\begin{array}{c}\text { Sample } \\
\text { Size }\end{array}$ \\
\hline $\begin{array}{l}\text { Sublic } \\
\text { Schools }\end{array}$ & 1. & $\begin{array}{l}\text { Community High School, Igbara, } \\
\text { Sango Ota }\end{array}$ & 195 & 0.55667 & 104 \\
& 2. & $\begin{array}{l}\text { African Church Community } \\
\text { Secondary School, Ewupe, Ota } \\
\text { Ado-Odo Senior High School, Alapoti } \\
\text { Road, Ado-Odo, Ota }\end{array}$ & 147 & 0.55667 & 80 \\
\hline $\begin{array}{l}\text { Private } \\
\text { Schools }\end{array}$ & 4. & $\begin{array}{l}\text { Glorious Scholars Academy, Ewupe, } \\
\text { Sango Ota }\end{array}$ & 68 & 0.55667 & 78 \\
& 5. & $\begin{array}{l}\text { Otanamic Brave Schools, Singer, Sango } \\
\text { Ota }\end{array}$ & 60 & 0.55667 & 33 \\
\hline & $\begin{array}{l}\text { Ota } \\
\text { Otal Graceland Academy, Ado-Odo, }\end{array}$ & 697 & 0.55667 & 40 \\
\hline
\end{tabular}

Source: Researcher's Field Work, February 2020.

\section{Research Instrument}

The study makes use of closed-ended questionnaires consisting of two sections as a primary data collection instrument. The questionnaires adopted are the Demographic Data Inventory (DDI), the Career Choice Scale (CCS) and the Support, Interference, and Lack of Engagement Scale (SIL). The 10-item DDI is designed by the researchers and has been used to gather data on some of the demographic characteristics of respondents such as school name, school type, gender, age, class, area of specialization, parents' educational qualifications, parents' occupational categories, and parents' socio-economic status. The CCS was adapted by the researchers from the CDS (Meyer \& Winer, 1993), a 4-point Likert-type instrument with 15 items, to measure the choice of career among adolescent students. The SIL Scale was developed by Boerchi and Tagliabue (2018) to measure students' perceptions of their parents' career-related behaviors and their influence on the students' behaviors. The SIL Scale consists of nine items in a 4-point Likert-type format with responses ranging from 1 = Strongly disagree, $2=$ Disagree, $3=$ Agree, to $4=$ Strongly agree . 
Idowu, S. A., Ifedayo, T. E., \& Idowu, E. O. (2020). Assessing the Career Conflict Options of Senior Secondary School Students of Ado-Odo Ota Local Government, Ogun State, Nigeria.

In the pilot analysis of these questionnaires, reliability tests were carried out to determine the internal consistency of each measure. Cronbach Alpha coefficients have been identified as follows: 0.87 for CCS, and 0.81 for SIL.

\section{Data Collection and Analysis Procedures}

For each of the secondary schools chosen for this study, researchers obtained primary data by seeking permission from the principals and school management prior to administering hard copies of the questionnaires with the aid of two research assistants. After receiving the consent of the administrators, the researchers called the students in their classrooms and made contact with them. The students were given the duration of three days to complete and return the questionnaires to the two research assistants, who sent them to the researchers for analysis.

Data obtained from field surveys using the DDI, CCS, and SIL questionnaires were sorted, compiled, and analyzed using various statistical tests using the IBM SPSS quantitative analysis software version 23 . The statistical methods used are a descriptive statistical technique and an inferential statistical technique. The demographic data of the respondents based on their school type, gender, age, class, area of specialization, fathers' and mothers' educational qualification, fathers' and mothers' occupational category, and parents' socio-economic status were analyzed using the descriptive statistical technique by using tables for simple frequency distribution and percentages. The inferential statistical technique that was used to analyze hypotheses 1, 2, and 3 is simple linear regression analysis, which was used to test the relationship between parents' level of formal education, parents' occupation, and parents' socio-economic status (independent variables) and career choices of senior secondary school students (dependent variable). All tests were carried out at 0.05 level of significance.

\section{Results}

This section presents the analysis and interpretation of data collected from the respondents through the questionnaires. It presents the demographic analysis of the respondents using descriptive statistics and the hypothesis testing using inferential statistics.

Demographic Analysis

Table 2. Demographic Characteristics of Respondents ( $n=373$ )

\begin{tabular}{|l|l|l|c|c|}
\hline S/N & Variables & Categories & Frequency & Percentage (\%) \\
\hline \multirow{2}{*}{1.} & \multirow{2}{*}{ School Type } & Public & 262 & 70.2 \\
\cline { 3 - 5 } & & Private & 111 & 29.8 \\
\hline \multirow{2}{*}{2.} & \multirow{2}{*}{ Gender } & Male & 166 & 44.5 \\
\cline { 3 - 5 } & & Female & 207 & 55.5 \\
\hline \multirow{2}{*}{3.} & Age & Below 15 & 92 & 24.7 \\
\cline { 3 - 5 } & & $15-18$ & 244 & 65.4 \\
\hline
\end{tabular}


Idowu, S. A., Ifedayo, T. E., \& Idowu, E. O. (2020). Assessing the Career Conflict Options of Senior Secondary School Students of Ado-Odo Ota Local Government, Ogun State, Nigeria.

\begin{tabular}{|c|c|c|c|c|}
\hline & & Over 18 & 37 & 9.9 \\
\hline \multirow[t]{3}{*}{4.} & \multirow[t]{3}{*}{ Class } & SSS 1 & 127 & 34.0 \\
\hline & & SSS 2 & 141 & 37.8 \\
\hline & & SSS 3 & 105 & 28.2 \\
\hline \multirow[t]{3}{*}{5.} & \multirow[t]{3}{*}{ Area of Specialization } & Art & 55 & 14.7 \\
\hline & & Commercial & 171 & 45.8 \\
\hline & & Science & 147 & 39.4 \\
\hline \multirow[t]{6}{*}{6.} & \multirow{6}{*}{$\begin{array}{l}\text { Father's Educational } \\
\text { Qualification }\end{array}$} & No Education & 19 & 5.1 \\
\hline & & Primary Education & 38 & 10.2 \\
\hline & & Secondary Education & 54 & 14.5 \\
\hline & & OND/NCE & 93 & 24.9 \\
\hline & & HND/B.SC & 93 & 24.9 \\
\hline & & Master's \& above & 76 & 20.4 \\
\hline \multirow[t]{6}{*}{7.} & \multirow{6}{*}{$\begin{array}{l}\text { Mother's Educational } \\
\text { Qualification }\end{array}$} & No Education & 37 & 9.9 \\
\hline & & Primary Education & 37 & 9.9 \\
\hline & & Secondary Education & 76 & 20.4 \\
\hline & & OND/NCE & 55 & 14.7 \\
\hline & & $\mathrm{HND} / \mathrm{B} . \mathrm{SC}$ & 94 & 25.2 \\
\hline & & Master's \& above & 74 & 19.8 \\
\hline \multirow[t]{3}{*}{8.} & \multirow{3}{*}{$\begin{array}{l}\text { Father's Occupational } \\
\text { Category }\end{array}$} & Senior Officer & 226 & 60.6 \\
\hline & & Middle-level Officer & 128 & 34.3 \\
\hline & & Junior Officer & 19 & 5.1 \\
\hline \multirow[t]{3}{*}{9.} & \multirow{3}{*}{$\begin{array}{l}\text { Mother's } \\
\text { Occupational Category }\end{array}$} & Senior Officer & 73 & 19.6 \\
\hline & & Middle-level Officer & 189 & 50.7 \\
\hline & & Junior Officer & 111 & 29.7 \\
\hline \multirow[t]{3}{*}{10.} & \multirow{3}{*}{$\begin{array}{l}\text { Parents' Socio- } \\
\text { Economic Status }\end{array}$} & High & 129 & 34.6 \\
\hline & & Middle & 207 & 55.5 \\
\hline & & Low & 37 & 9.9 \\
\hline
\end{tabular}

Source: Field Survey, February 2020.

Table 2 shows that the majority of participants (70.2\%) are from public secondary schools, while $29.8 \%$ are from private secondary schools. The majority of participants (55.5\%) are females, while $44.5 \%$ are males. The majority of participants (65.4\%) were between 15 and 18 years of age. This is followed by those who are under 15 years of age (24.7\%) and over 18 years of age (9.9\%). The majority of participants (37.8\%) are in SSS 2, 34.0\% are in SSS 1, and $28.2 \%$ are in SSS 3. The largest proportion of participants (45.8\%) are in the commercial class. This is followed by those in the science class (39.4\%) and the art class (14.7\%), respectively.

The largest proportion of participants (24.9\%) indicate that their fathers have a HND/B.Sc. degree. The same proportion of participants (24.9\%) note that their fathers have an OND/NCE qualification. It is followed successively by those who state that their fathers have master's 
Idowu, S. A., Ifedayo, T. E., \& Idowu, E. O. (2020). Assessing the Career Conflict Options of Senior Secondary School Students of Ado-Odo Ota Local Government, Ogun State, Nigeria.

degrees and above with $20.4 \%$, secondary education (14.5\%), primary education (10.2\%), and no formal education (5.1\%). The largest proportion of participants (25.2\%) indicate that their mothers have a HND/B.Sc. degree. It is followed sequentially by those who maintain that their mothers have secondary education (20.4\%), master's degree and above (19.8\%), OND/NCE (14.7\%), primary education (9.9\%), and no formal education (9.9\%).

Most of the participants (60.6\%) deem their fathers to be senior officers based on the occupation category. This is followed by those who submit that their fathers are middle-level officers $(34.3 \%)$ and junior officers $(5.1 \%)$. The majority of participants $(50.7 \%)$ consider their mothers to be middle-level officers with respect to occupation, accompanied successively by those who indicate that their mothers are junior officers (29.7\%) and senior officers (19.6\%). Finally, Table 2 shows that most of the participants (55.5\%) maintain that their parents have a middle socio-economic status, followed by those who claim that their parents have a high socio-economic status (34.6\%) and a low socio-economic status (9.9\%).

\section{Hypothesis Testing}

Hypothesis 1

Parents' level of formal education has significant impact on the career choices of senior secondary school students.

Table 3. Coefficients of Simple Linear Regression Analysis for the Impact of Parents' Education on Career Choice

\begin{tabular}{|c|c|c|c|c|c|}
\hline \multirow{2}{*}{ Model } & \multicolumn{2}{|c|}{$\begin{array}{c}\text { Unstandardized } \\
\text { Coefficients }\end{array}$} & $\begin{array}{c}\text { Standardized } \\
\text { Coefficients }\end{array}$ & & \\
\cline { 2 - 5 } & $\mathrm{B}$ & Std. Error & Beta & $\mathrm{t}$ & Sig. \\
\hline $\begin{array}{ll}\text { (Constant) } \\
\begin{array}{l}\text { Parents' Educational } \\
\text { Qualification }\end{array}\end{array}$ & 47.367 & 1.436 & & 32.977 & .000 \\
& -1.105 & .316 & -.179 & -3.499 & .001 \\
\hline
\end{tabular}

a. Dependent Variable: Career Choice

Source: Field Survey, February 2020.

Table 3 reveals significant results $(\beta=-.179, t=3.499, p<.05)$. Consequently, the null hypothesis, which stated that parents' level of formal education has no significant impact on the career choices of senior secondary school students, is therefore rejected in favor of the alternative hypothesis. Subsequently, it is concluded that the degree of formal education of parents has a significant impact on the career choice of senior secondary school students in the study area. 
Idowu, S. A., Ifedayo, T. E., \& Idowu, E. O. (2020). Assessing the Career Conflict Options of Senior Secondary School Students of Ado-Odo Ota Local Government, Ogun State, Nigeria.

Hypothesis 2

Parents' occupation has no significant impact on the career choices of senior secondary school students.

Table 4. Coefficients of Simple Linear Regression Analysis for the Impact of Parents' Occupation on Career Choice

\begin{tabular}{|c|c|c|c|c|c|c|}
\hline \multirow{2}{*}{\multicolumn{2}{|c|}{ Model }} & \multicolumn{2}{|c|}{$\begin{array}{c}\text { Unstandardized } \\
\text { Coefficients }\end{array}$} & \multirow{2}{*}{$\begin{array}{c}\text { Standardized } \\
\text { Coefficients }\end{array}$} & \multirow[b]{2}{*}{$\mathrm{t}$} & \multirow[b]{2}{*}{ Sig. } \\
\hline & & $\mathrm{B}$ & Std. Error & & & \\
\hline 1 & (Constant) & 40.211 & 1.343 & & 29.947 & .000 \\
\hline & Parents' Occupation & 1.695 & .860 & .102 & 1.970 & .050 \\
\hline
\end{tabular}

a. Dependent Variable: Career Choice

Source: Field Survey, February 2020.

Table 4 shows non-significant results $(\beta=-.102, t=1.970, p=.05)$. The null hypothesis, which states that parents' occupation does not have a significant impact on the career choices of senior secondary school students, is therefore upheld. Table 4 further reveals that career choice could be predicted from parents' occupation by means of the regression equation: Career Choice $=1.695 \times$ Parents' Occupation +40.211 . This means that the occupation of parents may or may not determine the career choices of senior secondary school students in the area of study.

Hypothesis 3

Parents' socio-economic status has no significant impact on the career choices of senior secondary school students.

Table 5. Coefficients of Simple Linear Regression Analysis for the Impact of Parents' Socio-Economic Status on Career Choice

\begin{tabular}{|c|c|c|c|c|c|c|}
\hline \multirow{2}{*}{\multicolumn{2}{|c|}{ Model }} & \multicolumn{2}{|c|}{$\begin{array}{l}\text { Unstandardized } \\
\text { Coefficients }\end{array}$} & \multirow{2}{*}{$\begin{array}{c}\text { Standardized } \\
\text { Coefficients }\end{array}$} & \multirow[b]{2}{*}{$\mathrm{t}$} & \multirow[b]{2}{*}{ Sig. } \\
\hline & & B & Std. Error & & & \\
\hline \multirow[t]{2}{*}{1} & (Constant) & 45.233 & 1.526 & & 29.650 & .000 \\
\hline & $\begin{array}{l}\text { Parents' Socio-Economic } \\
\text { Status }\end{array}$ & -1.468 & .820 & -.092 & -1.789 & .074 \\
\hline
\end{tabular}

a. Dependent Variable: Career Choice

Source: Field Survey, February 2020. 
Idowu, S. A., Ifedayo, T. E., \& Idowu, E. O. (2020). Assessing the Career Conflict Options of Senior Secondary School Students of Ado-Odo Ota Local Government, Ogun State, Nigeria.

Table 5 reveals non-significant findings $(\beta=-.092, t=1.789, p>.05)$. The null hypothesis, which states that parents' socio-economic status has no significant impact on the career choices of senior secondary school students, is therefore accepted. Table 5 further shows that career choice could be predicted slightly from parents' socio-economic status by means of the regression equation: Career Choice $=45.233-1.468 \times$ Parents' Socio-Economic Status.

\section{Discussion}

The findings on the demographic profile of respondents in Table 2 show that the majority of respondents $70.2 \%$ are from public secondary schools. The majority of respondents (65.4\%) are between 15 and 18 years of age. The findings also indicate that most of the respondents with $37.8 \%$ are in SSS 2. Also, the largest proportion of the respondents (45.8\%) are in the commercial class. The highest proportion of the respondents $(24.9 \%)$ indicate that their fathers have a HND/B.Sc. degree. The highest proportion of respondents $(25.2 \%)$ indicate that their mothers have a HND/B.Sc. degree. Most of the respondents (60.6\%) submit that their fathers are senior officers based on the occupation category. The majority of respondents (50.7\%) maintain that their mothers are middle-level officers with respect to occupation. The study also reveals that most of the respondents (55.5\%) maintain that their parents are of middle socioeconomic status.

The findings in research hypothesis 1 conclude that parents' level of formal education has a significant impact on the career choices of senior secondary school students in the study area. This coincides with the findings of Ogbiji (2019), who discovered that the children of parents with higher education are more likely to seek higher educational ambitions than those whose parents do not have higher educational qualifications. This finding is similar to the findings of Shahidul, Karim, and Mustari (2015), which reveal that the parental level of formal education had a positive impact on the career choice of secondary school students. Also, Hahs-Vaugh (2004) posits that parental education appears to have an impact on the academic and career development of students. On the contrary, Roach (2010) concludes that the highest level of parental education does not have an impact on the career selection of college students.

The finding in research hypothesis 2 reveals that career choice could be predicted from parents' occupation. This is in agreement with Williams (2016), who concluded that if the work of parents gives their children a great deal of happiness or offers a comfortable lifestyle, children would see the benefits early and can prefer their parents' careers over others. On the other hand, if parents complain about their work or struggle to support the family on the income that their work offers, children are more likely to pursue more satisfying or higher-paid careers. This finding is close to that of Aswani (2012), who found that the occupation of the parentsparticularly the mother-had a substantial positive effect on the educational and career ambitions of the standard eight pupils in Kenya. This study also coincides with the study of Saleem, Hanan, Saleem, Rao, and Shad (2015), which reveals that the occupations of parents play important roles in the selection of careers for their children. In his research on the relationship between parental occupations and the occupational preference of their children, 
Idowu, S. A., Ifedayo, T. E., \& Idowu, E. O. (2020). Assessing the Career Conflict Options of Senior Secondary School Students of Ado-Odo Ota Local Government, Ogun State, Nigeria.

Okeke (2003) discloses that the career paths of parents affects the career choices of their children. Mwaa (2016) also submits that parental occupation is one of the factors that influence students' career choices.

The finding in research hypothesis 3 states that the socio-economic status of parents does not have a significant impact on the career choices of secondary school students. The results show that the socio-economic status of the family does not significantly influence the student's career choice. Related to this study is the study of Obiyo and Eze (2015), which reveals that the socio-economic status of parents is not a strong predictor of the career aspirations of secondary school students. According to Taylor, Harris, and Taylor (2004), the socio-economic status of parents is insignificant in shaping students' career aspirations. Salawu and Bagudo (2000) have the same opinion that there is no significant relationship between the socioeconomic status of parents and the career aspirations of students. However, the results of this study are not consistent with the findings of Salgotra and Roma (2018) that the socio-economic status of parents has a significant effect on students' career aspirations.

\section{Conclusion}

This study concluded with four findings on demographic data, Hypothesis 1, Hypothesis 2, and Hypothesis 3. The demographic findings in Table 2 show the response of the respondents on their demographic characteristics and that of their parents. Hypothesis 1 concludes that the magnitude of parents' formal education has a substantial effect on the career choice of secondary school students. This suggests that the level of formal education of parents can affect the career choices of senior secondary school students, which means that the higher the standard of parents' education, the more knowledgeable the students will be when making career choices. Hypothesis 2 reveals that parents' occupation has slight significant impact on career choices of senior secondary school students. This implies that the occupation of parents has little influence in determining how senior secondary school students make decisions on their career choices. Finally, this study concluded in Hypothesis 3 that the socio-economic status of parents is not important to the career choices of senior secondary school students. This means that the socio-economic status (income) of the parent does not affect the career choices of secondary school students in the study area.

\section{Recommendations}

1. Since parental participation in student career choices is unavoidable, the current study recommends that parents be trained in career counseling. Schools should set up special community programs to help parents direct their children.

2. Counseling units in the Ministry of Education should coordinate orientation activities and provide information on the broad variety of career opportunities open to students. This will broaden the view of students as well as reveal the negative impact of family members on career choices. 
Idowu, S. A., Ifedayo, T. E., \& Idowu, E. O. (2020). Assessing the Career Conflict Options of Senior Secondary School Students of Ado-Odo Ota Local Government, Ogun State, Nigeria.

3. Parents should not push students against their will to pursue careers similar to their own. This is because the average number of students indicated that they would not choose a career similar to that of their parents.

4. A good parent-child relationship is important in shaping students ' career choices. In this regard, it is recommended that parents take time to discuss different career choices with their children and respect their decisions.

\section{Suggestions for Future Research}

This research only looked at the effect of parental factors on the career choice of senior secondary school students in the Ado-Odo Ota Local Government Area of Ogun State, Nigeria. Further studies should be carried out in the following areas:

1. Research should be carried out on the effect of teachers and school counsellors on career choices of senior secondary school students in Ado-Odo Ota Local Government Area of Ogun State, Nigeria.

2. Future research should focus on the impact of parental and peer group factors on career choices of senior secondary school students using a wider sample size because this study only made use of 373 participants in the Ado-Odo Ota Local Government Area of Ogun State, Nigeria. 3. Further studies should consider differences in parental factors that may influence the career choice of senior secondary school students. Variables such as parental educational background, parents' socio-economic status, parental expectations and values, and parents' occupation should be considered. 
Idowu, S. A., Ifedayo, T. E., \& Idowu, E. O. (2020). Assessing the Career Conflict Options of Senior Secondary School Students of Ado-Odo Ota Local Government, Ogun State, Nigeria.

\section{References}

Adelusi, A. A. (2003). Secondary school and career preference of adolescence in Eastern Nigeria and Lagos. West African Journal of Education, 2(3), 12-20.

Adya, M., \& Kaiser, K. (2005). Early determinants of women in the IT workforce: A model of girl's career choices. Information Technology \& People, 18(3), 230-259.

Alika, H. I., \& Egbochuku, E. O. (2009). Vocational interest, counselling, socio-economic status and age as correlates of the re-entry of girls into school. Edo Journal of Counselling, 2(1), 9-15. doi:10.4314/ejc.v2i1.52649

Alutu, C. C. (2001). Introduction to educational measurement and evaluation. Enugu: Joe Best Publishers.

Aswani, J. S. (2012). Some of the home environment factors that influence educational and occupational aspirations of standards eight pupils. Unpublished Master's thesis, Kenyatta University.

Boerchi, D., \& Tagliabue, S. (2018). Assessing students' perception of parental career-related support: Development of a new scale and a new taxonomy. International Journal for Educational and Vocational Guidance, 18(2), 181-201.

Bolles, R. N. (2011). What color is your parachute? A practical manual for job-hunters and career changers (11th ed.). Berkeley, CA: Ten Speed Press.

Bollu-steve, F. N., \& Sanni, W. O. (2013). Influence of family background on the academic performance of secondary school students in Nigeria. Ife Psychology, 21(1), 90-100.

Borchert, M. (2002). Career choice factors of high school students. Menomonie, WI: The Graduate School University of Wisconsin-Stout.

Bowlby, J. (1980). Attachment and loss. Loss, sadness and depression. New York: Basic Books.

Brown, D. (2002). The role of work and cultural values in occupational choice, satisfaction, and success: A theoretical statement. Journal of Counseling and Development, 80, 48-56.

Camarero-Figuerola, M., Dueñas, J. M., \& Renta-Davids, A. I. (2020). The relationship between family involvement and academic variables: A systematic review. Research in Social Sciences and Technology (RESSAT), 5(2), 57-71. https://doi.org/10.46303/ressat.05.02.4

Caplow, T. (1994). The sociology of work. Minneapolis: The University of Minnesota Press. 
Idowu, S. A., Ifedayo, T. E., \& Idowu, E. O. (2020). Assessing the Career Conflict Options of Senior Secondary School Students of Ado-Odo Ota Local Government, Ogun State, Nigeria.

Capuzzi, D., \& Stauffer, M. D. (2012). Career counselling: Foundations, perspectives and applications. New York: Routledge Taylor and Francis Group.

Carlos, M. A. (2009). Factors involved in the choice of dentistry as an occupation by Pernambuco dental students in Brazil. Unpublished Ph.D. Thesis, Brazil.

Chen, C. Y. (2018). Understanding school-family contact and academic and behavioral performance among adolescent students in Taiwan. International Journal of School \& Educational Psychology, 7(1), 42-55. doi:10.1080 / 21683603.2017.1385551

Christensen, L. B., Johnson, R. B., \& Turner, L. A. (2019). Research methods, design and analysis $\left(13^{\text {th }}\right.$ ed.). Boston, NJ: Pearson.

Considine, G., \& Zappala, G. (2002). The influence of social and economic disadvantages in the academic performance of school students in Australia. Journal of Sociology, 38(2), 129148. https://doi.org/10.1177/144078302128756543

Denga, D. I. (1990). Educational and vocational guidance of secondary school students in Nigeria. Jos: Savannah Press Limited.

Deridder, L. (1990). The impact of parents and parenting on career development. Knoxville, TN: Comprehensive Career Development Project (Ed 325 769).

Esters, L. T., \& Bowen, B. E. (2005). Factors influencing career choices of urban agricultural education students. Journal of Agricultural Education, 46(2), 24-35. doi:10.5032/jae.2005.02024

Eyo, M. B., \& Edet, P. B. (2011). Gender and occupational preferences among senior high school students in Cross River State Nigeria. An International Multidisciplinary Journal Ethiopia, 5(1), 327-341. doi:10.4314/afrrev.v5i1.64530

Fisher, T. A., \& Griggs, M. B. (1995). Factors that influence the career development of AfricanAmerican and Latino youth. The Journal of Vocational Education Research, 20(2), 57-74.

Gabriel, M. N., Muli, N. L., Muasya, I., Maonga I., \& Makhungulu, M. (2016). Parental socioeconomic status and academic achievement in selected secondary schools in urban informal settlements in Westlands Division, Nairobi country. Journal of Education and Social Science, 3(1), 43-55.

George, C. A., Cabrera, A. F., \& Kurban, E. R. (2018). Connecting school and home: Examining parental and school involvement in readiness for college through multilevel SEM. Research in Higher Education, 60(4), 553-575. 
Idowu, S. A., Ifedayo, T. E., \& Idowu, E. O. (2020). Assessing the Career Conflict Options of Senior Secondary School Students of Ado-Odo Ota Local Government, Ogun State, Nigeria.

Granger, M. J., Dick, G., Jacobson, C. M., \& Van Slyke, C. (2007). Information systems enrollments: Challenges and strategies. Journal of Information Systems Education, 18(3), 303-311.

Hahs-Vaughn, D. (2004). The impact of parents' education level on college students: An analysis using the beginning postsecondary students longitudinal study 1990-92/94. Journal of College Student Development, 45(5), 483-500.

Hairston, J. E. (2000). How parents influence African American students' decisions to prepare for vocational teaching careers. Journal of Career and Technical Education, 16(2), 5-15.

Hall, N. \& Quinn, R. (2014). Parental Involvement at the High School Level: Parents' Perspectives. Journal of Ethnic and Cultural Studies, 1(1), 13-21.

Idowu, S. A. (2019). Impact of leadership styles on employees' work performance in some south-western Nigerian private universities. Economic Insights - Trends and Challenges, $8(71), 27-46$.

Jungen, K. A. (2008). Parental influence and career choices: How parents affect the career aspiration of their children. Masters' Dissertation, University of Wiscosin-Scout.

Ketokivi, M., \& Mantere, S. (2010). Two strategies for inductive reasoning in organisational research. Academy of Management Review, 35(2), 315-333.

Kracke, B., Hany, E., Driesel-Lange, K., \& Schindler, N. (2013). Career decision of adolescent with university entrance qualification. In T. Brüggemann \& S. Rahn (Eds.), Career counselling: A text and a workbook. Münster: Waxmann.

Krippner, S. (1963). Junior high school students' vocational preferences and their parents' occupational levels. The Personnel and Guidance Journal, 41, 590-595.

Lankard, B. A. (1995). Family role in career development. ERIC Digest No. 164. ERIC Identifier: ED389878. Retrieved from https://files.eric.ed.gov/fulltext/ED389878.pdf

Lee, C. L. (1984). An investigation of the psychosocial variables in the occupational aspirations and expectations of rural black and white adolescents: Implication for vocational education. Journal of Research and Development in Education, 17(3), 28-34.

Lee, Y., \& Hughey, K. F. (2001). The relation of psychological separation and parental attachment to the career maturity of college freshmen from intact families. Journal of Career Development, 27(4), 279-293.

Leedy, P., \& Ormrod, J. (2001). Practical research: Planning and design (7 $7^{\text {th }}$ ed.). Upper Saddle River, NJ: Merrill Prentice Hall. Thousand Oaks: SAGE Publications. 
Idowu, S. A., Ifedayo, T. E., \& Idowu, E. O. (2020). Assessing the Career Conflict Options of Senior Secondary School Students of Ado-Odo Ota Local Government, Ogun State, Nigeria.

Leung S. A. (2008). The big five career theories. In J. A. Athanasou \& R. Van Esbroeck (Eds.), International handbook of career guidance. Dordrecht: Springer.

Meyer, B. W., \& Winer, J. L. (1993). The career decision scale and neuroticism. Journal of Career Assessment, 1(2), 171-180.

Montgomery, J. (1992). Factors that influence the career aspirations of mathematically precocious females. Paper presented at the Asian Conference on Giftedness: Growing up Gifted and Talented, Taipei, Taiwan, (ED 352 267).

Muraguri, J. M. (2011). Factors influencing degree choices among female undergraduate students at the University of Nairobi: A case study of the 2010/2011 cohort. Unpublished M.A. research project, University of Nairobi.

Muyoi, J. (2009). Factors Influencing career choice in schools. London: Cross Printers.

Mwaa, M. A. (2016). Parental factors influencing career choices among high school students in Nairobi County. Unpublished Research Project.

Napompech, K. (2011). What factors influence high school students in choosing cram school in Thailand. Paper presented at the International Conference on Business and Economics Research, IPEDR, 16, 90-95, IACSIT Press, Singapore. Retrieved June 12, 2020, from http://www.ipedr.com/vol16/17-ICBER2011-A20009.pdf

National Career Development Association. (2003). Career development: A policy statement of the National Career Development Association Board of Directors, adapted March 16, 1993, revised 2003. Retrieved January 22, 2020, from http://delawareebse.pbworks.com/f/NCDA\%20Career\%20Development\%20Policy\%20S tatement.pdf

Navin, D. S. (2009). Effects of dating and parental attachment on career exploration. University of New Hampshire.

Nwoke, M. B. (2011). Impact of age, gender and social factors on vocational choice among Nigerian adolescents. European Journal of Social Sciences, 19(4), 548-554.

Obiyo, N. O., \& Eze, C. O. (2015). Parental socio-economic-status as predictor of vocational aspirations of secondary school students in Nigeria: Implications for peace, curriculum planners and special educators. International Journal of Curriculum and Instruction, 7(2), 18-34.

Ogbiji, J. E. (2019). Parental socio-economic status and higher academic aspiration of senior secondary school students in Cross River State, Nigeria. Journal of Education and Training, 6(1), 55-63. 
Idowu, S. A., Ifedayo, T. E., \& Idowu, E. O. (2020). Assessing the Career Conflict Options of Senior Secondary School Students of Ado-Odo Ota Local Government, Ogun State, Nigeria.

Ogun State Government Official Website. (2020). Retrieved July 5, 2020, from http://ogunstate.gov.ng/mest/

Okeke, E. C. (2003). Relationship between parental occupations and children's occupational preference. NTI, Kaduna. [Unpublished PGDE Project].

Okobiah, O. C., \& Okorodudu, R. I. (2004). Issues, concepts, theories and techniques of guidance and counselling. Benin City: Ethiope Publishing.

Okonkwo, S. E. (2011). Guidance for 6-3-3-4 system of education, Zaria. Ahmadu Bello University.

Onyejiaku, F. O. (1980). Occupational choice among Nigerian youths and the need for guidance counsellors. The Calabar Educator, 1(1), 66-70.

Onyejiaku, F. O. (1987). Family influences on vocational aspirations of Nigerian secondary school students. Unpublished Study. University of Calabar.

Otto, L. B. (2000). Youth perspectives on parental career influence. Journal of Career Development, 27(2), 111-118. https://psycnet.apa.org/doi/10.1023/A:1007848600942

Patton, W., \& McMahon, M. (2014). Career development and systems theory: Connecting theory and practice (3rd ed.). Rotterdam: Sense Publishers.

Paul, L. (1962). The transition from school to work. London: Industrial Welfare Society.

Polenova, E., Vedral, A., Brisson, L., \& Zinn, L. (2018). Emerging between two worlds: A longitudinal study of career identity of students from Asian American immigrant families. Emerging Adulthood, 6, 53-65. doi: 10.1177/2167696817696430

Roach, K. L. (2010). The role of perceived parental influence on the career self-sufficiency of college students, counselor education. Unpublished Master's Thesis, College of BrockPort, State University of New York.

Roe, A. (1956). The psychology of occupations. New York: Wiley.

Salami, S. O. (2006). Influence of culture, family and individual differences on choice of genderdominated occupations among female students in tertiary institutions. Journal of Gender and Behaviour, 4(2), 814-833.

Salawu, A., A., \& Bagudo, A. A. (2000). Self-concept as a correlate of career choice of students in tertiary institution in Sokoto State. Nigerian Journal of Guidance and Counselling, 7(1), $1-11$. 
Idowu, S. A., Ifedayo, T. E., \& Idowu, E. O. (2020). Assessing the Career Conflict Options of Senior Secondary School Students of Ado-Odo Ota Local Government, Ogun State, Nigeria.

Saleem, N., Hanan, M. A. H., Saleem, I., Rao, S., \& Shad, R. M. (2015). Career selection: Role of parent's profession, mass media and personal choice. Bulletin of Education and Research, 36(2), 25-37.

Salgotra, A. K., \& Roma, K. (2018). Educational aspiration and socio-economic status among secondary school students. Journal of Humanities and Social Sciences, 23(3), 25-29.

Savickas, M. L. (2012). Life design: A paradigm for career intervention in the 21st century. Journal of Counseling \& Development, 90(1), 13-19.

Shahidul, S. M., Karim, A. H., \& Mustari, S. (2015). Social capital and educational aspirations of secondary school students: Does family social capital affect more compared to school social capital? International Education Studies, 8(2), 255-260. http://dx.doi.org/10.5539/ies.v8n12p255

Small, J., \& McClean M. (2002). Factors impacting on the choice of entrepreneurship as career by Barbadian youth: A preliminary assessment. Journal of Eastern Caribbean Studies, 27(4), 30-54.

Sylaj, V., \& Sylaj, A. K. (2020). Parents and teachers' attitudes toward written communication and its impact in the collaboration between them: Problem of social study education. Journal of Social Studies Education Research (JSSER), 11(1), 104-126.

Tan, C. Y. (2018). Involvement practices, socioeconomic status, and student science achievement: Insights from a typology of home and school involvement patterns. American Educational Research Journal, 56(3), 899-924.

Taylor, J., Harris, M. B., \& Taylor, S. (2004). Parents have their say...about their college-age children's career decision. NACE Journal, 64(2), 1-5.

Udoh, N. A., \& Sanni, K. B. (2012). Parental background variables and the career choice of secondary school students in Uyo Local Government Area, Nigeria. Mediterranean Journal of Social Sciences, 3(1), 497-504. doi:10.5901/mjss.2012.03.01.497

Vellymalay, S. K. (2012). Parental involvement at home: Analyzing the influence of parents' socioeconomic status. Studies in Sociology of Science, 3(1), 1-6.

Watson, C. M., Quatman, T., \& Edler, E. (2002). Career aspiration of adolescent girls. Effects of achievement level, grade and single sex school environment sex role. Journal of Research, 46(9), 323-335.

Whiston, S. C., \& Keller, B. K. (2004). The influences of the family origin on career development: A review and analysis. The Counselling Psychologist, 32(4), 493-568. 
Idowu, S. A., Ifedayo, T. E., \& Idowu, E. O. (2020). Assessing the Career Conflict Options of Senior Secondary School Students of Ado-Odo Ota Local Government, Ogun State, Nigeria.

Williams, E. (2016). The effect of parents on an adolescent's choice of career. Retrieved from https://work.chron.com/effect-parents-adolescents-choice-career-18063.html

Yamane, T. (1973). Statistics: An introductory analysis. (3rd ed.). New York: Harper and Row. 